\title{
Pineapple quality in a traditional cultivation system in different soil classes
}

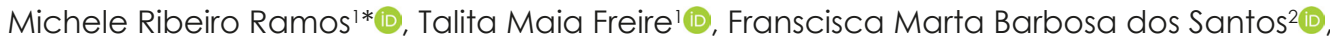

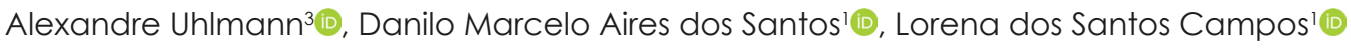 \\ IState University of Tocantins, Palmas, Brazil \\ ${ }^{2}$ Department of Agriculture, Livestock and Aquaculture of Tocantins, Palmas, Brazil \\ ${ }^{3}$ Embrapa Forestry, Colombo, Brazil \\ *Corresponding author, e-mail: michele.rr@unitins.br
}

\begin{abstract}
Pineapple (Ananas comosus (L.) Merril) is considered one of the most important fruits of the tropical and subtropical regions, and the third most-produced in the world due to its high commercial expansion in the world market, in recent years. Therefore, this work aimed to evaluate the influence of landscape position on pineapple quality. The work was developed at the Providência Farm, located in the municipality of Miracema do Tocantins. The following soil parameters were evaluated: hydraulic conductivity - KS, soil bulk density - DS, and total porosity - TP, as well as the following quality attributes: titratable acidity - TA, length and diameter of infructescences, total fresh mass - TM, fresh mass of infructescences - IM, and soluble solids - SS. The analyses were performed at the Agri-Environmental Laboratory of the Agricultural Sciences Complex of the Federal University of Tocantins. Less massive infructescences developed on more porous soils. The variation in the mass of infructescences is not associated with soil types, but rather with soil porosity. Soils with higher KS tend to increase the chances of producing infructescences with high acidity and high levels of soluble solids. The DS did not result in a significant association with the pineapple quality attributes. The infructescences were not affected by the landscape position. No position in the landscape influenced fruit quality. In general, the infructescences showed low acidity and low levels of soluble solids, with length and diameter of infructescences below the standard of the cultivar 'Pérola'.
\end{abstract}

Keywords: agricultural production factors, fruit growing, soil

\section{Introduction}

Pineapple (Ananas comosus (L.) Merril) is one of the most important fruit species in tropical and subtropical regions and the third most consumed in the world, behind only bananas and citrus fruits (Nadzirah et al., 2013) given its high commercial expansion in the world market, in the last few years (Kist et al., 2017).

Brazil is one of the world's largest pineapple producers. However, the exportation of these fruits is still inexpressive, since, in the national territory, the pineapple cultivar 'Pérola' is still predominant, although presenting features that are considered obstacles for the international market, such as a conic shape, a whitecolored pulp, and the presence of spines on the leaves (Viana et al., 2013).

The state of Tocantins presents a privileged geographic localization, constituting an important highway junction and presenting favorable climate and environmental factors to fruit production with a high degree of quality (Nogueira et al., 2014). About 35.3\% of the municipalities in this state are dedicated to the commercial cultivation of pineapple, whose fruits present excellent quality, a reason why they reach the best prices in the national market (Matos \& Sanches, 2016).

In 2018, the national cultivated area was 71,553 ha, with a production of 1,766,986 thousand fruits, and the state of Tocantins ranked in the seventh position (3.91\%) of national production (IBGE, 2019). In that regard, the distribution of production in tons per physiographic regions in 2018 (IBGE, 2019) shows the North region with the highest participation (34.06\%), followed by the Northeast (33.59\%) and Southeast (26.91\%), regions that, jointly, contribute with $94.56 \%$ of national production.

Due to the high availability of soil and relief in the state of Tocantins, production is often performed heterogeneously, producing fruits with different quality. 
Another important factor is the technological level of the producer. Since the species is planted by average and small producers, the investment applied on soil preparation, fertilization recommendations, liming, and especially plant spacing, and other agricultural practices is often inadequate. Could soil variability, as a consequence of landscape position, affect the fruit quality of pineapple?

In short, the different types of soil, as a consequence of relief and parent material, are mainly associated with the processes of water detachment, water storage, and susceptibility to erosion. This will consequently reflect on soil thickness, volume of available water, outflow, moisture, and water retention at different capacities. All these characteristics shall influence the vegetative growth of plants, including the incidence of pests and diseases (Victorino, 2015). In this manner, this study aimed to evaluate the influence of soil type on pineapple infructescence quality.

\section{Material and Methods Study Area}

The work was developed within Providência Farm, a private property (Figure 1) in the municipality of Miracema do Tocantins, state of Tocantins $109^{\circ} 32^{\prime 2} 22^{\prime \prime}$ $S$; $48^{\circ} 22^{\prime} 55^{\prime \prime}$ W). The elevation of the area is 190 meters, located within the Cerrado Biome. Geologically, Miracema do Tocantins is limited at the west by the Paraguay-Araguaia fold belt, and at the south by the Goiás Massif. According to Caputo (2006), several of the unconformities attributed to the Parnaíba Basin reflect the participation of sea-level variations, unrelated to globalscale tectonics, and may also involve non-diastrophic events (such as climatic variations). In the specific place of the experiment, there is the emergence of rocks of the Canindé Group (Poti Formation). This formation is formed by whitish-gray sandstone interspersed and interlaminated with shale and siltstone, which were deposited along deltas and tidal flats under the occasional influence of storms, in the Eocarboniferous (Góes \& Feijó, 1994).

The climate of the region, according to the data by Seplan (2012) and ANA (2018), is classified as C2wA"a" (humid, subhumid climate, with moderate water deficiency in winter), characterized by two welldefined seasons: a rainy season from November to April, and a dry season from May to October. The rainfall index varied from 1,600 to $1,800 \mathrm{~mm} /$ year, and January is the rainiest month (Figure 2).

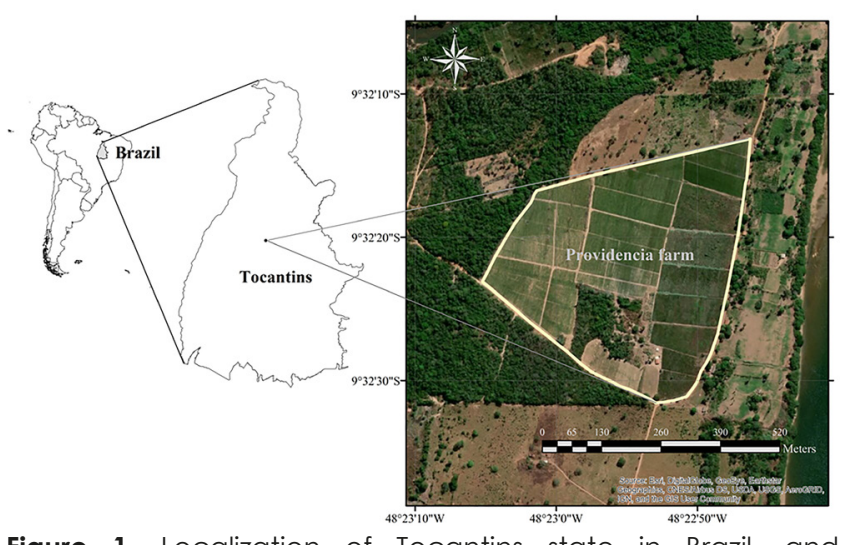

Figure 1. Localization of Tocantins state in Brazil, and Providencia farm.

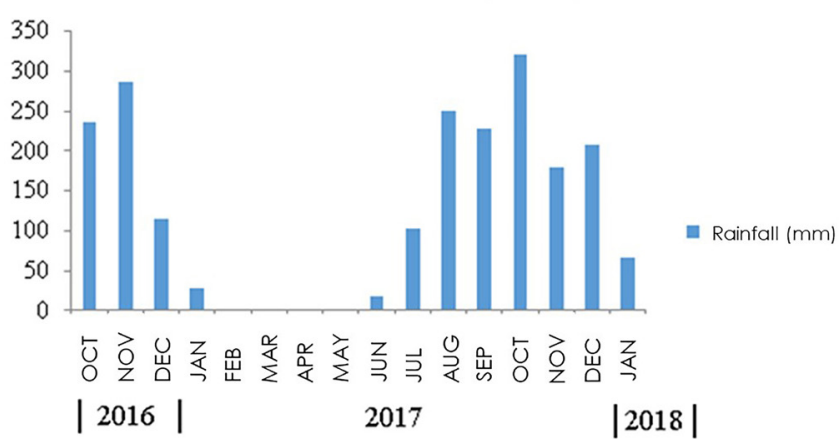

Area Preparation and Crop Management

The property presents 21,122 hectares divided into production stands and the administrative headquarters. In August 2016, the native vegetation (Cerrado) was removed from an area with 4.83 hectares (study area), constituting the first cropping season in this plot and the fourth in the property.

The preparation of the area for planting began with the removal of the native vegetation (Cerrado), followed by land slashing, and then by burning. Afterward, the plowing of the area was performed, followed by two harrowings (in both directions of the terrain) to reach a 30 $\mathrm{cm}$ depth and thus facilitate root development.

Before the pineapple planting, $4+\mathrm{ha}^{-1}$ of limestone and $2+\mathrm{ha}^{-1}$ of $\mathrm{P}_{2} \mathrm{O}_{5}$ were applied, without a technical recommendation. The recommended spacing for the crop is $0.90 \times 0.30 \mathrm{~m}$ in simple rows, according to Gomes et al. (2003). However, the producer adopted $0.80 \times 0.45 \mathrm{~m}$. These behaviors justify the lack of technical knowledge by the producer, adopting management practices without recommendation. Unfortunately, this traditional cultivation is the reality of pineapple planting in the region.

The pineapple variety cultivated is the 'Pérola'. The seedlings were originated from the production of the previous season. The size of the cultivated area was 4.83 hectares, with approximately 134.000 seedlings. 
The planting of the seedlings was performed in planting rows, opened with a hoe. After the opening of the planting rows with an equivalent depth to the third part of the seedling length, the seedlings were distributed on the soil, taking care to prevent soil from entering leaf rosette.

Irrigation was performed in a gun sprinkler irrigation system, in the drought period (August to October). An ethephon-based floral inducer was applied from 8 to 14 months before flowering, aiming at inducing a more uniform flowering. The area was cultivated only with pineapple, without soil turning or other agricultural practices.

\section{Sampling}

There is an elevation difference regarding the topography of the terrain, providing two distinctlandscape positions (upper third and lower third), according to Figure 3. In this manner, the area was divided into three stands, namely stand 1 ( 1.7 hectares), stand 2 (1.62 hectares), and stand 3 (1.51 hectares) (Figure 4).

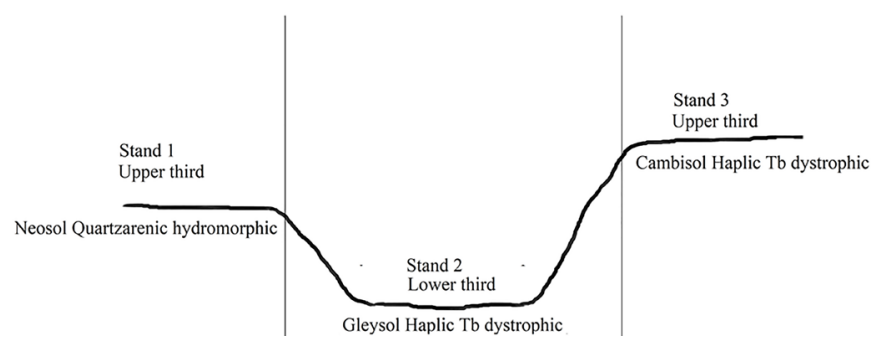

Figure 3. Cross-section of study area depicting the topography and soil classes distribution in the landscape.

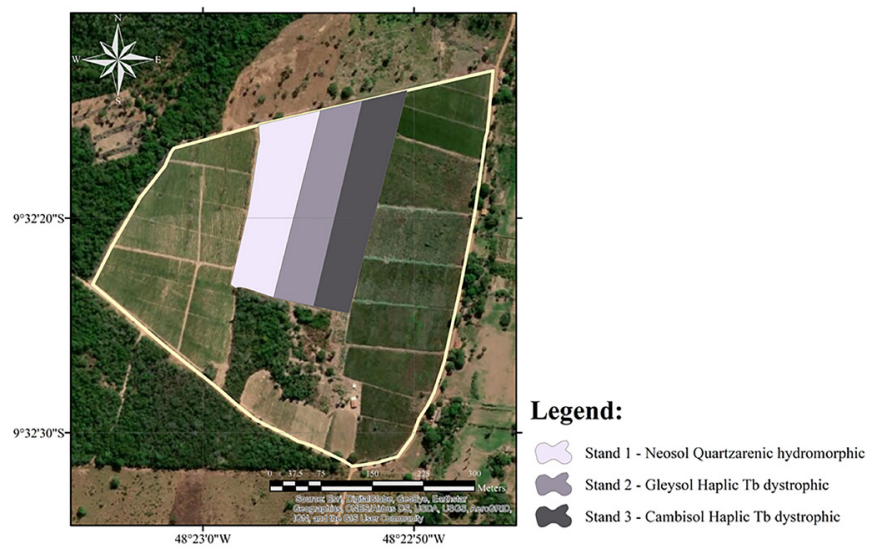

Figure 4. Study area inside the Providência farm and location of three stands from where pineapple and soil samples were collected, according to the three soil classes.

The identification of soil classes in each one of the three stands was made through the opening of small trenches, as well as thought many observation spots by using auger samplings (Figure 4). These procedures allow the identification of three soil classes (Santos et al., 2018): Cambisol Haplic Tb dystrophic, Gleysol Haplic Tb dystrophic with humic A horizon, and Neosol Quartzarenic hydromorphic (presence of soil mottling from $35 \mathrm{~cm}$ of depth) (Figures 3 and 4).

Intending the soil chemical characterization, it was collected deformed soil samples in a zigzagdistributed spots. Twenty single samples were collected per stand at the depth from 0 to $20 \mathrm{~cm}$. The samples were mixed, providing a composite sample with approximately $1,000 \mathrm{~g}$, being representative of the plot.

The soil samples were used for the determination of the following chemical parameters: contents of micronutrients, soil organic matter, $\mathrm{K}, \mathrm{Ca}^{2+}, \mathrm{Mg}^{2+}, \mathrm{P}$ (Mehlich), $\mathrm{Na}, \mathrm{S}, \mathrm{Al}^{3+}, \mathrm{H}+\mathrm{Al}$, cation exchange capacity (C.E.C) at $\mathrm{pH} 7.0, \mathrm{pH}\left(\mathrm{CaCl}_{2}\right)$, base saturation (V\%), sum of bases (SB), saturation by aluminum ( $m \%)$, and contents of sand, silt, and clay (Teixeira et al., 2017).

Afterward, undeformed soil samples were randomly collected within each plot (metallic ring Kopecky), with a $73.44 \mathrm{~cm}^{-3}$ volume, with five duplicate samples per plot, totaling 15 samples.

The harvest of the pineapples was performed in January 2018 by collecting five infructescences per stand, in the same georeferenced spots where has been collected the undeformed soil samples. The collection was performed with the aid of a machete, cutting the stem at approximately $5 \mathrm{~cm}$ below the infructescence.

\section{Measuring of soil physical attributes}

The saturated hydraulic conductivity was determined using the methodology preconized by Teixeira et al. (2017). The set of Kopecky rings collected was placed in a vat containing water, until reaching soil saturation. Afterward, the set was transferred to the support of the permeameter. The percolated was collected in a $500 \mathrm{~mL}$ beaker. The rings were placed on screens, and the reservoir tube was leveled so that the lower part was at the same level of the upper part of the ring, maintaining a hydraulic load with $2 \mathrm{~cm}$ height. With the aid of a wash bottle, water was carefully deposited. In the first ring, the stopper was manually removed, preventing air from entering the system. The moment of the beginning of percolation in each ring was observed and registered. The percolated volume was measured with a graduated cylinder after 10, 20,30, 40, 50, and 60 minutes. The evaluations must be continued after this period if the coefficient of variation of the three last samples is greater than $20 \%$. Lastly, the percolated volume was registered.

The bulk density was also determined according 
to Teixeira et al. (2017). The undeformed samples were weighed and subjected to drying in a forced-air oven at $105^{\circ} \mathrm{C}$ for 48 hours, and the density was obtained through the soil mass and the volume of the metallic ring; after this time, the sample was removed and placed to cool in a desiccator, being afterward weighed. The total porosity was determined by the difference between the watersaturated soil mass and the soil mass dried at $105^{\circ} \mathrm{C}$ in the oven (Teixeira et al., 2017).

\section{Fruit evaluation}

Titratable Acidity (TA)

According to the methodology by Zenebon \& Tiglea (2008), $1 \mathrm{~g}$ of the homogenized infructescence sample was weighed, macerated with the aid of a crucible, and the extracted juice was diluted with approximately $25 \mathrm{~mL}$ of water in an Erlenmeyer flask, which was then sealed and left to rest for 30 minutes. Afterward, 4 drops of phenolphthalein were added, followed by titration with $0.1 \mathrm{~N}$ sodium hydroxide, under constant agitation, until the pink coloration persisted for 30 seconds.

\section{Total Fresh Mass (TM)}

The fresh mass was obtained by the individua weighing of each infructescence in a semi-analytical precision balance.

Fresh Mass of Infructescence (IM)

The crown was removed from all infructescences, and the weighing of each fruit was verified individually in a semi-analytical precision balance.

\section{Infructescence Diameter (D) and Height (H)}

The infructescences were measured with a measuring tape to determine their length and diameter.

\section{Soluble Solids (SS)}

The contents of soluble solids were determined with the aid of an RHB32 analogical refractometer for ${ }^{\circ}$ Brix, using the homogenized extracted juice, as described for the TA. 2 drops of the sample were placed between the prisms of the device, and after one minute the reading was performed directly, in the Brix degree scale at $20^{\circ} \mathrm{C}$ (Brasil, 1986).

\section{Statistical Analysis}

The matrix containing the six morphological and chemical descriptors of the pineapple infructescences (matrix Y) was used to construct a correlation matrix between these variables, to which a principal component analysis (PCA) were applied. The purpose was to perform the ordering of the observations, as well as to reduce the number of dimensions of the original matrix of descriptors.

The eigenvalues extracted from both matrixes were used to guide the selection of the most important axes, aiming at constructing ordination diagrams and, also, to obtain the scores resulting from these selected axes for further analyses.

The scores of the eigenvalues extracted from matrix $Y$ were used as response variables in linear multiple regression models, in which three descriptors of the soil physical properties were used as predictors. Afterward, the best predictors were selected through a doublecriteria forward stepwise approach (Blanchet et al., 2008), and the normality of residuals were verified through the Shapiro-Wilk test, besides being graphically evaluated regarding their homoscedasticity and linearity (Quinn \& Keough, 2002). These analytical procedures aimed at finding relationships between the soil physical attributes and pineapple fruit descriptors.

After that, it was also applied a principal component analysis to the correlation matrix of the three soil physical parameters (matrix X) aiming to ordering data and, also, reduce their dimensionality (redundancy).

The eigenvectors with eigenvalues higher than one $\left(\lambda_{p} \geq 1\right)$ extracted from matrixes $X$ and $Y$ were selected, and we applied their respective scores to the analysis of variance. The objective was to test the hypothesis that the morphological and biochemical descriptors of the pineapple infructescences (contained in matrix $Y$ ) are influenced by soil classes. It has been tested if there were identifiable differences in the set of physic characteristics among soil classes. The assumptions of the model were investigated by the Levene (homoscedasticity) and graphic tests regarding the normality and linearity of residuals.

\section{Results and Discussion}

The mean of the chemical attributes and soil particle size used for the characterization of the study area are presented in Table 1. In spite of the different soil classes present in the area, the values of $\mathrm{V} \%, S B, S O M$, and CEC are similar, with a difference only in the content of clay, with the Quartzarenic Neosol being the sandiest soil, an essential feature to classify it as such.

Another attribute is the presence of mottling, a feature that led to the designation of hydromorphic soil and constitutes an indication of water accumulation in the soil. This hydromorphy is also verified in the Gleysol, which is in a lower position than the last one, differently from the Cambisol, which is in a higher position than the 
other two previously mentioned.

In this manner, the chemical attributes indicate that the soils are not base saturated, that is, they present low fertility. If there is any factor that may have influenced the response on fruit quality, that is certainly not the chemical fertility of the soils. The results of the mean of chemical attributes and pineapple features are presented in Table 2 and indicated according to the type of soil.

Table 1. Mean of the chemical attributes and particle size of the soil cultivated with pineapple in Miracema do Tocantins.

\begin{tabular}{|c|c|c|c|c|c|c|c|c|c|c|c|c|c|c|c|c|c|}
\hline \multirow{2}{*}{$\begin{array}{c}\text { Depth } \\
* * * \mathrm{~cm}^{* * *}\end{array}$} & $\mathrm{pH}$ & P Mehlich & $K$ & $\mathrm{Na}$ & $\mathrm{Ca}^{2}$ & $\mathrm{Mg}^{2}$ & $S$ & SB & $\mathrm{Al}^{3}$ & $\mathrm{H}+\mathrm{A}$ & E.C pH 7.0 & V & $M$ & S.O.M & Clay & Sand & Silt \\
\hline & $\mathrm{CaCl}_{2}$ & $* * * * * \mathrm{mg}$ & g. $\mathrm{dm}^{3 * *}$ & k*** & & & & * cmc & $\mathrm{c} \cdot \mathrm{dm}$ & & & & & & & & ** \\
\hline & \multicolumn{17}{|c|}{ Plot 1 - Dystrophic Tb Haplic Cambisol } \\
\hline \multirow[t]{2}{*}{$0-20$} & 4.3 & 13.0 & 144.0 & 6.3 & 1.8 & 0.6 & 5.0 & 3.04 & 0.4 & 5.8 & 8.57 & 32.3 & 12.6 & 2.3 & 21 & 41 & 38 \\
\hline & \multicolumn{17}{|c|}{ Plot 2 - Dystrophic Tb Haplic Gleysol with humic A horizon } \\
\hline $0-20$ & 4.2 & 27.1 & 213.0 & 7.2 & 1.6 & 0.4 & 5.6 & 2.94 & 0.9 & 7.2 & 9.74 & 26.0 & 26.1 & 2.2 & 29 & 37.3 & 33.7 \\
\hline \multicolumn{18}{|c|}{ Plot 3 - Hydromorphic Quartzarenic Neosol } \\
\hline $0-20$ & 4.1 & 7.3 & 110.0 & 6.3 & 0.8 & 0.3 & 6.4 & 1.59 & 0.6 & 5.8 & 7.18 & 19.2 & 30.3 & 1.7 & 14 & 62 & 24 \\
\hline
\end{tabular}

Table 2. Mean of the morphological and biochemical attributes of the pineapples cultivated at the Providência Farm, in Miracema do Tocantins.

\begin{tabular}{|c|c|c|c|c|c|}
\hline Total Fresh Mass & Fresh Mass of Infructescence & Diameter & Height & Titratable Acidity & \multirow{2}{*}{$\begin{array}{l}\text { Soluble Solids } \\
{ }^{* * *}{ }^{\circ} \text { Brix } \\
* * *\end{array}$} \\
\hline & *** $g^{* * * * * * * * * * * * *}$ & \multicolumn{2}{|c|}{$* * * * * * \mathrm{~cm}^{* * * * * *}$} & $* * * * \%$ **** & \\
\hline \multicolumn{6}{|c|}{ Plot 1 - Dystrophic Tb Haplic Cambisol } \\
\hline 1.003 & 0.86 & 9.26 & 16.9 & 0.062 & 11.710 \\
\hline \multicolumn{6}{|c|}{ Plot 2 - Dystrophic Tb Haplic Gleysol with humic A horizon } \\
\hline 0.937 & 0.78 & 9.27 & 14.1 & 0.061 & 11.620 \\
\hline \multicolumn{6}{|c|}{ Plot 3 - Hydromorphic Quartzarenic Neosol } \\
\hline 1.027 & 0.87 & 9.37 & 17.4 & 0.047 & 10.670 \\
\hline
\end{tabular}

The application of the principal component analysis to the matrix $Y$ resulted in the capture of most of the original variance $(70 \%)$ by only two axes (Table 3). The first axis of the analysis seems to summarize the information relative to the mass of infructescences, whereas the second axis seems to be related to the chemical parameters (TA and SS), and finally, the third axis seems to associate with the unidimensional parameters of infructescence size ( $\mathrm{H}$ and $\mathrm{D}$ ) (Table 4).

Table 3. Eigenvalues and percentage of variance explained by the axes extracted from a principal component analysis (PCA) applied to the matrix $Y$ of morphological and biochemical descriptors of pineapple infructescences.

\begin{tabular}{cccc}
\hline Axis & Eigenvalue & \% of variance & Cumulative \% of variance \\
\hline 1 & 2.53 & 42.11 & 42.11 \\
2 & 1.68 & 28.04 & 70.15 \\
3 & 0.93 & 15.54 & 85.69 \\
\hline
\end{tabular}

Table 4. Loading matrices showing the correlation between the descriptors contained in the matrix $Y$ and the scores of the three first axes extracted by the principal component analysis

\begin{tabular}{ccccccc}
\hline Axis/Descriptors & $\mathrm{TM}^{1}$ & $\mathrm{IM}^{2}$ & $\mathrm{D}^{3}$ & $\mathrm{H}^{4}$ & $\mathrm{TA}^{5}$ & $\mathrm{SS}^{6}$ \\
\hline 1 & 0.60 & 0.58 & 0.36 & 0.36 & -0.11 & 0.14 \\
2 & 0.11 & 0.22 & -0.32 & -0.25 & 0.66 & 0.58 \\
3 & 0.03 & 0.06 & -0.64 & 0.68 & 0.20 & -0.31 \\
\hline T: Total fresh mass; : : Dry mass of infructescence; 3: Diameter; & 4: Height; 5: Titratable acidity; ;: \\
Soluble solids. & & & & & &
\end{tabular}

After the extraction of the eigenvalues from the correlation matrix, derived from the matrix $Y$, it was obtained only two models with a statistical level of significance.

The first model pointed toward an association of the scores of the PCA axis 1 and total porosity (TP). The model explained approximately $32 \%$ of the associated variance between the predictor and the response variable (Table 5). It is worth noting that the negative association between response and predictor (Figure 5) indicates that the higher the soil total porosity (TP), the lower the mass infructescences (given the positive association between the mass of infructescences and the scores of PCA axis 1 - Table 4). It is also easy to understand, based on Figure 6-II, that the mass variation in the infructescences of the sample (summarized by axis 1 of the PCA) does not associate with the types of soils, despite the soil samples obtained from the Quartzarenic Neosol were different from those obtained in the two remaining soil classes (Figure 6-I). Axis 1, therefore, seems to divide the infructescences as to their mass, with this characteristic being associated with soil porosity, but not necessarily with the soil classes. In other words, soil porosity is determining the mass of the infructescences. The pineapples produced in less porous soils tended to reach a higher mass.

The second model was generated based on the association between the PCA axis 2 and the hydraulic conductivity predictor (KS). The model curiously explained the same percentage of variance $(32 \%)$ but pointed toward a direct association between the two variables 
Table 5. Statistical parameters of the models generated by regression analysis applied to the axes extracted from matrix Y through principal component analysis (PCA). Model 1 presented the scores of axis 1 of the PCA as the response variable and the total porosity (TP) of the soil samples as the predictor variable. Model 2 presented the scores of axis 2 of the PCA as the response variable and the hydraulic conductivity (KS) of the soil samples as the predictor variable.

\begin{tabular}{cccc}
\hline \multicolumn{4}{c}{ Model 1 } \\
Parameter & Response (PCA1) & Parameter & Predictor (TP) \\
\hline$R^{1}$ & -0.61 & $B^{5}$ & -0.61 \\
$R^{2}$ aj. ${ }^{2}$ & 0.32 & $E P(\beta)^{6}$ & 0.22 \\
$F^{3}$ & 7.56 & $T^{7}$ & -2.75 \\
$P^{4}$ & 0.017 & $P^{8}$ & 0.017 \\
& \multicolumn{3}{c}{ Model 2 }
\end{tabular}

\begin{tabular}{|c|c|c|c|}
\hline Parameter & Response (PCA2) & Parameter & Predictor (KS) \\
\hline$R$ & 0.61 & $B$ & 0.61 \\
\hline$R^{2} a j$. & 0.32 & $\operatorname{EP}(\beta)$ & 0.22 \\
\hline$F$ & 7.73 & $T$ & 2.78 \\
\hline$P$ & 0.016 & $P$ & 0.016 \\
\hline
\end{tabular}

: Equation coefficient; 6 : Standard error of B (beta); 7 : Student's test; $8:$ Probability.
(Table 5). By admitting a positive association between the axis 2 of the PCA and the chemical descriptors of the infructescences (total acidity: TA and soluble solids: SS - see Table 4), it may be concluded that the ordination plane illustrated in Figure 5 tends to segment the samples according to the variation of these characteristics. Those less acids and with the lowest values of soluble solids tent to be positioned in the lower quadrants of the diagram, and the opposite for the upper quadrants. Since the hydraulic conductivity vector is positively associated with this same axis, soils with higher KS tend to increase the chances of infructescence with high acidity and high contents of soluble solids. It is also true that the variance associated with the axis 2 of the PCA distributes the observations (infructescence samples) according to the types of soils (Figure 6-III). The samples obtained from the crop developed on Neosol Quartzarenic tends

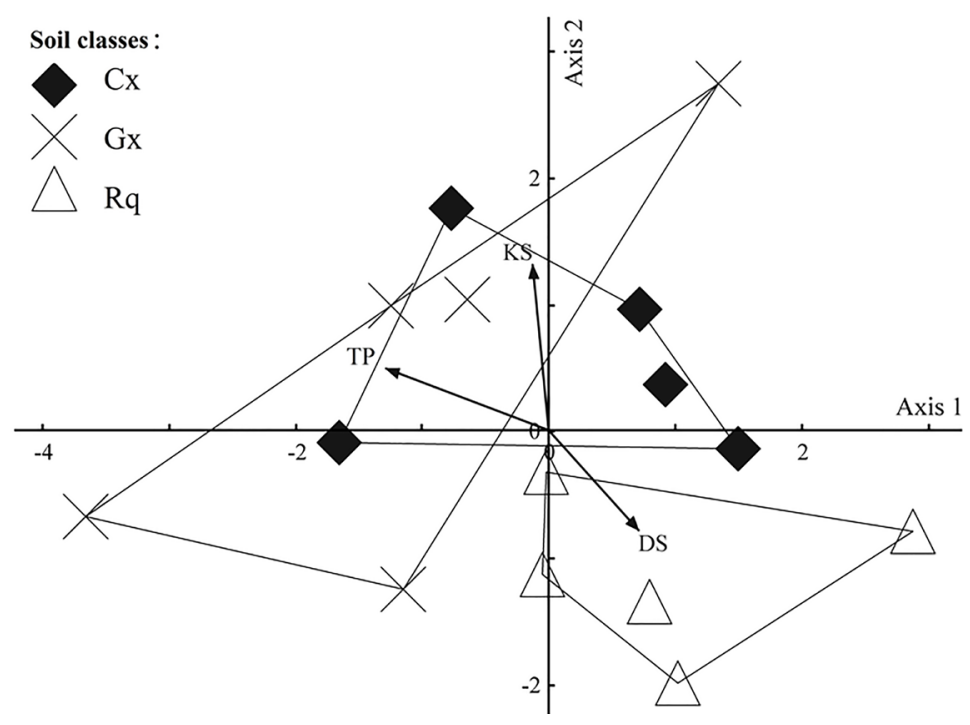

Figure 5. Ordination diagram resulting from the application of the principal component analysis (PCA) to the correlation matrix between the six morphological and biochemical descriptors of pineapple infructescences (matrix Y). The arrows represent the three descriptors of soil physical characteristics (KS - Hydraulic Conductivity; DS - Soil Density; TP - Total Porosity). The longer and more subparallel are the arrows, the higher will be the coefficient of correlation between the soil descriptor (represented by the arrows) and the ordination axis. Soil classes: Cx Cambisol Haplic; Gx - Gleysol Haplic; RQ - Neosol Quartzarenic.

to be positioned in the lower quadrant of the ordination diagram, always associated with a lower soil hydraulic conductivity and lower acidity/lower content of soluble solids of the infructescences. This distinction is reinforced by the data illustrated in Figure 6-III. Even so, there is no apparent distinction between the features of the Haplic Cambisol and the Haplic Gleysol (Figure 6-I and 6-III). In short, the results indicate that pineapple cultivation on Neosol Quartzarenic, with low hydraulic conductivity, implies in higher chances of low acidity and lower content of soluble solids in the infructescences.
The third model tested, with the scores of the axis 3 of the PCA applied to the data of matrix $Y$, although resulting in the selection of the soil bulk density (DS) descriptor, did not result in a significant association of these variables. Due to that, the data will not be presented.

None of the adjusted models presented a significant deviation from the assumption of normality of residuals (verified by the Shapiro-Wilk test), nor did the graphic verification allow detecting important shifts in the assumption of homoscedasticity. 

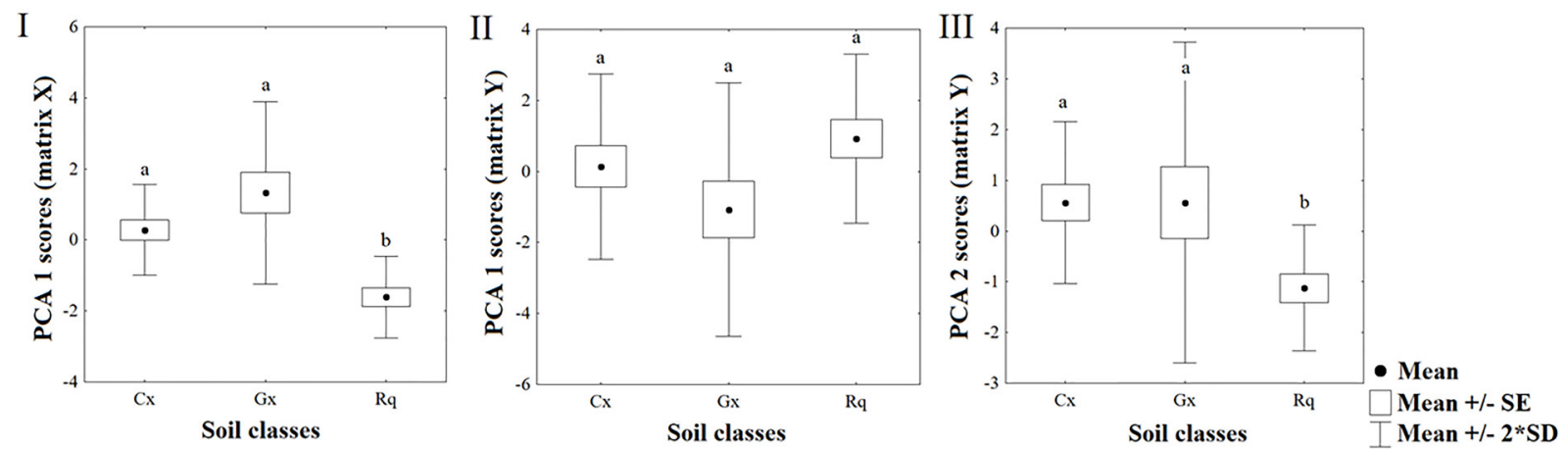

Figure 6. Box-plot illustrating the mean, standard error (SE), and standard deviation (2XSD) of the scores: I) related to the first axis of the PCA applied to matrix X (soil physical descriptors); II) related to the first axis of the PCA applied to matrix $Y$ (morphological and chemical descriptors of pineapple infructescences), and III) related to the second axis of the PCA applied to the same matrix Y, according to the soil classes (Cx - Cambisol Haplic; Gx - Gleysol Haplic; RQ - Neosol Quartzarenic). Different letters represent a significant statistical difference according to the post hoc Fisher test (ns=5\%).

The titratable acidity verified in Table 2 shows that the infructescences present $0.062 \%$ in the Haplic Cambisol, $0.061 \%$ in the Gleysol Haplic, and $0.047 \%$ of citric acid in the Quartzarenic Neosol. According to (Bleinroth, 1987), the acidity of the pineapple cv. 'Pérola' varies from $0.32 \%$ to $1.22 \%$; we thus verify that the pineapples produced in the Neosol Quartzarenic present the highest acidity content, whereas the pineapples produced in the Haplic Cambisol and Haplic Gleysol exhibited a very close content of citric acid, and a little below when compared with the infructescences produced in the farm.

Regarding the values of soluble solids (Table $2)$, the infructescences produced in the Cambisol Haplic presented $11.710^{\circ}$ Brix; those of the Gleysol Haplic presented $11.620^{\circ}$ Brix, and those of the Neosol Quartzarenic presented $10.670^{\circ}$ Brix. All pineapples harvested presented content of soluble solids below the indicated for the cultivar 'Pérola', which is at least $12^{\circ}$ Brix (CQH/CEAGESP, 2003).

Among the infructescences harvest, those produced in the Cambisol Haplic were the sweeter ones, considering that this plot presents the highest hydraulic conductivity, which provided sweeter and more acid pineapples. The infructescences produced in the Gleysol Haplic are intermediate, possibly for being a soil with poor drainage, hindering soil aeration, which are bad characteristics for the crop.

These results show that the pineapples studied lack acidity and present low contents of soluble solids. With that, we can affirm that the infructescences do not present a good chemical quality since they do not possess a minimum acidity and are not sweet, compared to the pineapples of the cultivar 'Pérola' (CQH/CEAGESP, 2003; Viana et al., 2013; Berilli et al., 2011).

Regarding the total fresh mass (Table 2), the Haplic Cambisol presented infructescences with 1,003 g, whereas the Haplic Gleysol presented $0.937 \mathrm{~g}$, and the Quartzarenic Neosol presented 1,027 g. The commercial classification of the pineapple practiced by the CQH/ CEAGESP (2003) divides pineapples into six categories, in which the harvested infructescences are in the type 1 class, with mass varying from 900 to $1,200 \mathrm{~g}$.

According to (Pereira et al., 2009), the weight considered optimal for the pineapple cv. 'Pérola' is within 1.0-1.4 kg; therefore, we can affirm that the infructescences produced in the Haplic Cambisol and Quartzarenic Neosol are within the minimum limit for the total fresh mass, whereas the infructescences of the Haplic Gleysol are below the fresh mass average. In this study, a trend toward larger lengths and diameters was observed for the infructescences with higher mass.

The pineapples with higher total fresh mass were produced in the soil with the lowest total porosity (Quartzarenic Neosol). For being a sandy soil, it ensured good soil drainage and aeration, being indicated for pineapple production.

The mean values of diameter and height of infructescences, presented in Table 2, indicate that the infructescences produced in the Cambisol Haplic (9.26 $\mathrm{cm}$ and $16.9 \mathrm{~cm})$, Gleysol Haplic $(9.27 \mathrm{~cm}$ and $14.1 \mathrm{~cm})$, and Neosol Quartzarenic $(9.37 \mathrm{~cm}$ and $17.4 \mathrm{~cm}$ ), present an inferior diameter to the standard of the cultivar 'Pérola' (Pereira et al., 2009), directly influencing the total fresh mass of pineapples, which are undesirable characteristics for consumers, who prefer larger and heavier pineapples.

Cardoso et al. (2013) report that the population density of pineapple plants interferes directly with the yield. Aguiar et al. (2014) say that a wider plant spacing provides larger pineapples and lower yield, a different result from that found in this study, in which the producer cultivated the pineapples with a population density below the recommended density of 30,000 to 40,000 plants 
per hectare (Pádua et al., 2016), and also harvested small infructescences, evidencing the influence of soil characteristics as a preponderant factor in the process.

The management employed in the pineapple crop showed to be insufficient in all soil classes studied. However, it is observed that in the soil with a sandy texture, the potential to produce better quality infructescences was higher than in the remaining soils.

Fruit quality was compromised mainly due to the traditional management that the producers still perform. We also highlight that the lack of technical knowledge and assistance may be decisive in the production process, and that, regardless of the soil good aptitude for cultivation, the agricultural practices, soil management, plant spacing etc., are factors that can limit production and, consequently, result in low-quality infructescences, with a lower aggregate price.

\section{Conclusions}

Generally, the quality of the infructescences was inferior to the standard of the pineapple cultivar 'Peróla', mainly due to the management employed int he cultivation, which is performed empirically, representing the reality of most small producers in the region. However, considering that the management performed in all studied areas was the same, the inherent features to each soil were decisive in the differences found for the evaluated parameters of the infructescences. These differences are mainly related to the parent material and especially to the relief, both responsible for soil formation. In the Quartzarenic Neosol, the pineapples were larger and heavier than in the other soil classes. However, the chemical characteristics of the infructescence were better in the other classes in comparison to the sandy soil, even being below the standard.

\section{References}

Aguiar, A.T.E., Gonçalves, C., Paterniani, M.E.A.G.Z., Tucci, M.L.S., Carlos Castro, E.F. 2014. Instruções agrícolas para as principais culturas econômicas. Instituto Agronômico, Campinas, Brazil. $452 \mathrm{p}$.

ANA. Agência Nacional das Água. Séries Históricas de Estações. 2019. http://www.snirh.gov.br/hidroweb/ publico/medicoes_historicas_abas.jsf<Access on 19 oct. 2019>

Berilli, S.S., Almeida, S.B., Carvalho, A.J.C., Freitas, S.J., Berilli, A.P.C.G., Santos, P.C. 2011. Avaliação sensorial dos frutos de cultivares de abacaxi para consumo in natura. Revista Brasileira de Fruticultura Special issue: 592-598.

Blanchet, G., Legendre, P., Bocard, D. 2008. Forward selection of spatial explanatory variables. Ecology 89: 2623-2632.
Bleinroth, E.W. 1987. Matéria-prima. In: Medina, J. C. (ed.) Abacaxi: cultura, matéria-prima, processamento e aspectos econômicos. ITAL, Campinas, Brazil. p. 133-164.

BRASIL. Ministério da Agricultura. 1986. Métodos analíticos de bebidas e vinagre. Diário Oficial da República Federativa do Brasil, Brasília, Brazil.

Caputo, M.V. 2006. Evolução tectônica da bacia do Parnaíba, qual é a influência das orogenias? In: Simpósio De Geologia da Amazônia Belém/Pará, 2006. SBGnúcleo norte, Belém, Brazil.

Cardoso, M.M., Pegoraro, R.F., Maia, V.M., Kondo, M.K., Fernandes, L.A. 2013. Crescimento do abacaxizeiro 'Vitória' irrigado sob diferentes densidades populacionais, fontes e doses de nitrogênio. Revista Brasileira de Fruticultura 35: 769-781.

CQH/CEAGESP. Centro de qualidade de horticultura/ Companhia de entrepostos e armazéns gerais de São Paulo. 2003. Programa brasileiro para a modernização da horticultura: normas de classificação do abacaxi. CEAGESP, São Paulo, Brazil.

Goés, A.M., Feijó, F.J. 1994. Bacia do Parnaíba. Boletim de Geociências da PETROBRAS. Petrobras, Rio de Janeiro, Brazil.

Gomes, J.A., Ventura, J.A., Alves, F.L., Arleu, R.J., Rocha, M.A.M., Salgado, J.S. 2003. Recomendações técnicas para a cultura do abacaxizeiro. INCAPER, Vitória, Brazil. 28 p.

IBGE. Instituto Brasileiro de Geografia e Estatística. 2019. Produção Agrícola Municipal, 2019. https://sidra.ibge. gov.br/Tabela/1612\#resultado< Access on 19 sept. 2019>

Kist, B.B., Santos, C.E., Carvalho, C., Treichel, M., Filter, C.F. 2017. Anuário Brasileiro de Fruticultura. Editora Gazeta, Santa Cruz do Sul, Brazil. 88 p.

Matos, A.P., Sanches, N.F. 2016. Sistema de Produção Integrada para a Cultura do Abacaxi no Estado do Tocantins. Embrapa Mandioca e Fruticultura, Cruz das Almas, Brazil. 44 p.

Nadzirah, K.Z., Zainal, S., Noriham, A., Normah, I., Siti Roha, A.M., Nadya, H. 2013. Physico-chemical properties of pineapple variety N36 harvested and stored at different maturity stages. International Food Research Journal 20: 225-231.

Nogueira, S.R., Lima, F.S.O., Rocha, E.M., Araújo, D.H.M. 2014. Fungicidas no controle de fusariose do abacaxi no estado de Tocantins, Brasil. Revista de Ciências Agrárias 37: 447-455.

Pádua, T.R.P., Matos, A.P., Reis, R.C., Viana, E.S., Sasaki, F.F.C. 2016. Plantio e densidade populacional para as cultivares de abacaxi Pérola e BRS Imperial em sistema orgânico de produção na região de Lençóis, Chapada Diamantina - BA. Embrapa Mandioca e Fruticultura, Cruz das Almas, Brazil. 4 p.

Pereira, M.A.B., Siebeneichler, S.C., Lorençoni, R., Adorian, G.C., Silva, J.C., Garcia, R.B.M., Pequeno, D.N.L., Souza, 
C.M., Brito, R.F.F. 2009. Qualidade do fruto de abacaxi comercializado pela cooperfruto - Miranorte - TO. Revista Brasileira de Fruticultura 31: 1048-1053.

Quinn, G.R., Keough, M.J. 2002. Experimental design and data analysis for biologists. Cambridge University Press, Cambridge, UK. 537 p.

Santos, H.G., Jacomine, P.K.T., Anjos, L.H.C., Oliveira, V.A., Lumbreras, J.F., Coelho, M. R., Almeida, J.A., Filho, J.C.A., Oliveira, J.B., Cunha, T.J.F. 2018. Sistema Brasileiro de Classificação de Solos. 5. ed. Embrapa, Brasília, Brazil. $356 \mathrm{p}$.

SEPLAN. Secretaria do Planejamento e Orçamento. Base de dados cartográficas do Tocantins. Arquivos digitais. 2012.

Teixeira, P.C., Donagemma, G.K., Fontana, A., Teixeira, Q.G. 2017. Manual de métodos de análise de solos. 3. ed. Embrapa, Brasília, Brazil. 573 p.

Viana, E.S., Reis, R.C., Jesus, J.L., Junghans, D.T., Souza, F.V.D. 2013. Caracterização físico-química de novos híbridos de abacaxi resistentes à fusariose. Revista Ciência Rural Online 43: 155-1161.

Victorino, G.F.S. 2015. O efeito da posição topográfica no desenvolvimento, produtividade e qualidade em diferentes castas na vinha. 99f. (M.Sc. Thesis) Universidade de Lisboa, Lisboa, Portugal.

Zenebon, O., Tiglea, N.S.P.P. 2008. Métodos FísicoQuímicos para Análise de Alimentos. 4. ed. Instituto Adolfo Lutz, São Paulo, Brazil. 1020 p.

Conflict of Interest Statement: The authors declare that the research was conducted in the absence of any commercial or financial relationships that could be construed as a potential conflict of interest.

All the contents of this journal, except where otherwise noted, is licensed under a Creative Commons Attribution License attribuition-type BY. 